\title{
PERAN FAKTOR INTERNAL DAN EKSTERNAL DALAM MEMODERASI PENGARUH STRATEGI CUSTOMER FOCUS UNTUK MENINGKATKAN DAYA SAING KOPERASI (Studi Pada Koperasi Di Kota Batu)
}

\author{
Ita Athia \\ Dosen Fakultas Ekonomi \& Bisnis Universitas Islam Malang \\ Email : itathia@gmail.com
}

\begin{abstract}
Abstrak
Penelitian ini dilatarbelakangi oleh adanya anggapan bahwa koperasi di Indonesia yang mayoritas dianggap sebagai badan usaha yang tidak mempunyai daya saing. Kondisi empiris mengungkapkan bahwa koperasi belum bisa mensejahterakan anggotanya sendiri, bahkan banyak koperasi yang mengalami kegagalan dan bubar akibat berbagai faktor.

Tujuan penelitian ini adalah untuk memberikan perspektif kepada koperasi tentang pentingnya menggarap anggota dengan menggunakan customer focus dengan mempertimbangkan faktor internal dan eksternal yang dimiliki koperasi itu sendiri. Dengan strategi customer focus, koperasi tidak harus memenangkan persaingan dengan cara mencari banyak pelanggan baru, melainkan memenangkan persaingan dengan cara fokus kepada anggota yang loyal. Anggota yang loyal akan tetap bertahan dan mendukung perusahaan bahkan pada saat perusahaan tersebut berada pada kondisi yang paling buruk.

Penelitian ini tergolong dalam penelitian kuantitatif, dan termasuk field research dengan pendekatan explanatory atau confirmatory. Penelitian ini dilaksanakan selama 5 bulan, dengan jumlah responden sebesar 133 responden yang terdiri dari pengurus, pengawas, manajer, karyawan dan anggota dari 7 koperasi di kota Batu yang telah dipilih secara purposive. Analisis data yang digunakan adalah Path Analysis dengan bantuan SPSS versi 18.0.

Temuan yang dihasilkan adalah strategi customer focus berpengaruh secara signifikan meningkatkan daya saing koperasi. Faktor internal dan eksternal merupakan variabel moderating yang bisa dipakai bersama-sama customer focus untuk menambah peningkatan daya saing koperasi.

Beberapa faktor internal dan eksternal pada koperasi perlu dipertahankan dan harus mendapatkan perhatian lebih untuk mendukung keberhasilan pelaksanaan customer focus sehingga koperasi bisa berdaya saing dengan badan usaha lainnya.
\end{abstract}

Kata kunci : customer focus, faktor internal, faktor eksternal, daya saing koperasi.

\begin{abstract}
This research is motivated by the assumption that the majority of cooperatives in Indonesia are considered as business entities that do not have competitiveness. Empirical conditions reveal that cooperatives have not been able to prosper their own members, even many cooperatives have failed and disbanded due to various factors.

The purpose of this study is to provide a perspective to the cooperative about the importance of working on members by using customer focus by considering internal and external factors that are owned by the cooperative itself. With a customer focus strategy, cooperatives do not have to win the competition by finding many new customers, but winning the competition by focusing on loyal
\end{abstract}


members. Loyal members will survive and support the company even when the company is at its worst.

This research is classified as quantitative research, and includes field research with an explanatory or confirmatory approach. This research was carried out for 5 months, with the number of respondents amounting to 133 respondents consisting of administrators, supervisors, managers, employees and members of 7 cooperatives in the city of Batu which had been selected purposively. Data analysis used was Path Analysis with the help of SPSS version 18.0.

The resulting findings are an influential customer focus strategy that significantly improves the competitiveness of cooperatives. Internal and external factors are moderating variables that can be used together with customer focus to increase cooperative competitiveness.

Some internal and external factors in the cooperative need to be maintained and must get more attention to support the successful implementation of customer focus so that cooperatives can be competitive with other business entities.

Keyword : customer focus, internal factors, external factors, cooperative competitiveness

\section{PENDAHULUAN}

Koperasi sampai dengan saat ini masih terkesan tradisional dan jauh dari kata profesional. Stigma negatif dari masyarakat masih sering disematkan oleh masyarakat kepada koperasi sebagai badan usaha nomor dua atau bahkan ketiga setelah BUMS dan BUMN/BUMD. Anggapan ini beralasan karena sebagian besar koperasi di Indonesia masih belum dikelola dengan menggunakan sentuhan manajemen yang wajib dilakukan oleh badan usaha yang berorientasi pada keuntungan. Kondisi empiris mengungkapkan bahwa banyak sekali koperasi yang ada di Indonesia tidak dapat mensejahterakan anggotanya bahkan banyak yang mengalami kegagalan seiring dengan waktu sehingga bubar dengan sendirinya akibat berbagai faktor (Suprayitno, 2007). Beberapa penelitian menyimpulkan bahwa banyak anggota koperasi yang belum merasa puas akan pelayanan yang telah diberikan oleh koperasi. Hal ini tercermin pada adanya kesenjangan antara kualitas pelayanan yang mampu diberikan koperasi dibandingkan dengan yang diharapkan oleh anggota koperasi (Agustin, 2013; Eliyawati, 2015; Purba, 2018).

Secara kuantitatif perkembangan koperasi di Indonesia menunjukkan perkembangan yang sangat pesat pada setiap tahunnya, dari data yang dilansir dari kementrian Koperasi dan UKM, Jawa Timur merupakan propinsi yang memiliki jumlah koperasi terbanyak di Indonesia. Oleh karenanya, Jawa Timur meraih prestasi sebagai penggerak Koperasi terbaik Nasional. Namun dibalik potensi itu masih terdapat kendala dan masalah yang dihadapi, antara lain masih banyak koperasi yang ditutup karena tidak aktif, pemanfaatan SDM di lingkungan oleh koperasi belum optimal, dan jaringan koperasi yang berjalan tersegmentasi belum mencapai skala usaha optimal dan rapuh kelangsungannya. Pemerintah pusat maupun daerah terus menstimulus pembangunan koperasi agar menjadi koperasi yang sehat dan berkualitas, mampu meningkatkan jumlah anggota dan fokus pada penguatan kelembangaan koperasi sebagai badan usaha yang efektif dan efisien, sehingga mampu berdaya saing tinggi. 
Tabel 1. Jumlah Koperasi di Tingkat Nasional, Propinsi Jawa Timur dan Kota Batu

\begin{tabular}{|l|l|l|l|}
\hline Keterangan & Nasional & Jatim & Kota Batu \\
\hline Total koperasi & 212.315 & 31.182 & 192 \\
\hline Koperasi tidak aktif & 61.912 & 3.710 & 56 \\
\hline Koperasi aktif & 150.223 & 27.472 & 132 \\
\hline Koperasi sehat (dari koperasi yang aktif) & 58.107 & 12.434 & 46 \\
\hline
\end{tabular}

Sumber: depkop.go.id; dinas koperasi dan disperindag kota Batu, 2018

Koperasi mempunyai pasar internal yang merupakan captive market (pasar yang dapat dikuasai), yaitu anggotanya sendiri, yang apabila dikelola secara profesional koperasi bisa memenangkan persaingan dalam memperebutkan pasar atau mempertahankan keeksistensiannya. Captive market inilah yang sebenarnya merupakan keunggulan bersaing yang tidak dimiliki oleh badan usaha lainnya di luar koperasi. Koperasi seharusnya benar-benar mengoptimalkan kebutuhan dan keinginan para anggotanya terlebih dahulu sebelum berekspansi melayani pasar ekternalnya.

Penelitian ini akan mencoba memberikan perspektif kepada koperasi tentang pentingnya menggarap pasar internalnya dengan menggunakan strategi customer focus, untuk memenangkan persaingan tidak dengan cara mendapatkan pelanggan yang banyak, melainkan memenangkan persaingan dengan cara fokus pada pelanggan yang loyal. Beberapa riset menunjukkan bahwa perusahaan memiliki kesempatan baik untuk bertahan, dan bahkan berkembang saat kondisi ekonomi semakin berat, jika mereka memiliki pelanggan yang lebih loyal dari competitor mereka. Pelanggan yang loyal akan tetap bertahan dan mendukung perusahaan bahkan pada saat perusahaan tersebut berada pada kondisi yang paling buruk.

Customer focus yang digunakan sebagai strategi marketing ini tentunya harus dirumuskan dengan mempertimbangkan faktor-faktor baik internal maupun eksternal yang dimiliki oleh koperasi. Perencanaan strategis merupakan bagian penting bagi perusahaan dalam usahanya mencapai tujuan. Perencanaan strategis khususnya di Indonesia, umumnya masih dianggap hal yang tidak terlalu penting bagi badan usaha yang berskala kecil menengah. Strategi bisnis dirasa hanya perlu dilakukan oleh perusahaan-perusahaan yang berskala besar. Padahal dengan mengidentifikasi kekuatan dan kelemahan yang dipunyai, perusahaan baik itu besar maupun kecil dapat merumuskan strateginya untuk menghadapi lingkungan eksternal yang seringkali berubah dengan cepat dan dipenuhi dengan ketidakpastian. Penelitian mengenai pemasaran strategis yang diterapkan pada koperasi di Indonesia masih sangat minim. Penelitian ini merupakan pengembangan dari penelitian-penelitian terdahulu dengan melihat seberapa jauh peranan faktor intenal yang dimiliki oleh koperasi dan faktor eksternalnya yang dapat mendukung koperasi untuk melaksanakan stategi customer focus dalam rangka meningkatkan daya saingnya. 


\section{KAJIAN TEORI}

\section{Pemasaran Koperasi}

Koperasi pada dasarnya adalah organisasi yang terdiri dari beberapa anggota yang bekerja bersama-sama untuk memenuhi kesejahteraanya. ICA (International Cooperative Alliance) menegaskan bahwa tujuan didirikannya koperasi adalah untuk membantu memperbaiki kehidupan sosial ekonomi anggotanya dengan saling bekerja sama dan tolong menolong.

Dalam sistem kerja koperasi, anggota berstatus ganda, Ropke (1985) menjelaskan bahwa anggota koperasi adalah pemilik dan sekaligus sebagai pelanggan utama koperasi. Sebagai pemilik, anggota berhak mengendalikan jalannya koperasi dan mengambil kebijakan-kebijakan strategis tentang operasional koperasi, seperti jenis produk, bentuk pelayanan, kualitas produk dan pelayanan, harga, rantai distribusi, dan lain sebagainya. Sebaliknya, sebagai pelanggan, anggota berhak untuk mendapatkan kepuasan atas pelayanan yang diberikan koperasi.

Sebagai organisasi bisnis, tentunya koperasi juga berorientasi terhadap keuntungan. Oleh karena itu koperasi tetap harus menggunakan strategi pemasaran dalam rangka mempertahankan eksistensinya di pasar. Pada dasarnya koperasi menghadapi dua pasar potensial yang berbeda, yaitu pasar internal (internalize market) dan pasar eksternal (externalize market) (Hendar, 2010). Pasar internal menggambarkan transaksi bisnis antara koperasi dengan para anggotanya, sedangkan pasar eksternal menggambarkan transaksi bisnis antara koperasi dengan konsumen non anggota.

Pengertian manajemen pemasaran menurut beberapa ahli pemasaran (Stanton, Kotler, 1975, 1980) adalah suatu perencaaan yang dibuat oleh organisasi agar organisasi atau perusahaan dapat bersaing dengan baik di pasar, sehingga dapat mencapai tujuan yang telah ditetapkan bersama. Manajemen pemasaran dalam koperasi merupakan suatu hal yang sangat vital dan sangat berpengaruh terhadap maju atau mundurnya koperasi. Koperasi sebagai lembaga pemasaran, adalah lembaga yang mengadakan kegiatan pemasaran, menyalurkan barang dari produsen ke konsumen, serta mempunyai hubungan organisasi. Berdasarkan prinsip identitas koperasi, anggota koperasi mempunyai status ganda, yaitu sebagai pemilik sekaligus sebagai pelanggan, maka memberikan pelayanan kepada anggota harus benar-benar memuaskan.

Falsafah konsep pemasaran (Limakrisna dan Susilo, 2012) bertujuan untuk memberikan kepuasan terhadap keinginan dan kebutuhan konsumen, sehingga konsep pemasaran yang diterapkan dapat merupakan falsafah bisnis yang menyatakan bahwa pemuasan kebutuhan konsumen merupakan syarat ekonomis dan sosial bagi kelangsungan hidup institusi, agar mendapat laba dalam jangka panjang. Selanjutnya Institusi memprioritaskan untuk berfokus pada pelanggan, dan kinerja institusi didefinisikan dengan mempertimbangkan faktor eksternal, yaitu dari perspektif pelanggan yang ditargetkan, sehingga merupakan pendorong mendasar pembelian (Wang dan Lo, 2004). 


\section{Strategi Customer Focus}

Customer Focus menjadi poin yang sangat penting dalam upaya mencapai kepuasan pelanggan. ISO (International Standart Organization) 9001 meletakkan customer focus pada posisi teratas dalam 7 prinsip sistem manajemen mutunya. Customer focus adalah prioritas utama dengan memberikan semua kebutuhan yang melebihi harapan customer untuk ketercapaian kepuasan pelanggan, sehingga keberlangsungan hidup perusahaan akan terjamin dalam waktu yang panjang. Organisasi bergantung pada pelanggan mereka dan oleh karena itu harus memahami kebutuhan saat ini dan masa depan, harus memenuhi persyaratan pelanggan dan berusaha untuk melebihkan harapan pelanggan (ISO 9001:2015). ISO menegaskan bahwa standar mutu ini dapat diterapkan pada berbagai organisasi, besar ataupun kecil, apapun produk dan layanannya, dalam berbagai aktivitas sektor, apakah itu perusahaan bisnis, layanan publik atau departemen pemerintahan.

Whitely dalam Goetsch dan Davis (1994) mengemukakan karakteristik organisasi yang sukses dalam membentuk fokus pada pelanggan, antara lain yaitu:

1. Visi, komitmen, dan suasana,

Manajemen perlu menunjukkan baik dalam kata-kata tertulis maupun tindakan, bahwa organisasi memiliki komitmen besar terhadap kepuasan pelanggan.

2. Penjajaran dengan pelanggan,

Organisasi perlu menyejajarkan dirinya dengan pelanggannya, hal ini tercermin dalam beberapa hal, antara lain yaitu: a). pelanggan berperan sebagai penasehat dalam penjualan produk dan pelayanan, b). pelanggan tidak dijanjikan sesuatu yang lebih daripada apa yang bisa diberikan, c). karyawan memahami product knowledge yang dihargai pelanggan, d). masukan dan umpan balik dari pelanggan dimasukkan dalam proses pengembangan produk/layanan.

3. Kemauan untuk mengidentifikasi dan mengatasi permasalahan pelanggan,

Perusahaan harus selalu berusaha untuk mengidentifikasi dan mengatasi permasalahan para pelanggannya. Hal ini tercermin dalam hal, a). keluhan pelanggan dipantau dan dianalisa, b). selalu mengupayakan adanya umpan balik dari pelanggan, c). organisasi berusaha mengidentifikasi dan menghilangkan proses, prosedur, dan sistem internal yang tidak menciptakan nilai bagi pelanggan.

4. Memanfaatkan informasi dari pelanggan,

Organisasi tidak hanya mengumpulkan umpan balik dari pelanggan, tetapi juga memanfaatkannya dalam rangka melakukan perbaikan. Pemanfaatan informasi dari pelanggan ini tercermin pada a). semua karyawan memahami bagaimana pelanggan menentukan kualitas, b). karyawan di semua level diberi kesempatan untuk bertemu dengan pelanggan, c). karyawan mengetahui siapa yang menjadi pelanggan sesungguhnya, d). organisasi memberikan informasi yang membantu terciptanya harapan realistis kepada para pelanggan, prinsipnya adalah janjikan apa yang bisa diberikan, tetapi berikan lebih dari yang 
dijanjikan, dan e). manajer dan karyawan memahami kebutuhan dan harapan pelanggan.

5. Mendekati para pelanggan,

Berdasarkan pendekatan TQM (Total Quality Management), organisasi tidak cukup hanya pasif menunggu umpan balik dari pelanggannya. Berbagai bidang yang kompetitif menuntut pendekatan yang lebih aktif. Mendekati pelanggan berarti melakukan hal-hal seperti a). memudahkan pelanggan untuk menjalankan bisnis, b). berusaha mengatasi semua keluhan pelanggan, c). memudahkan pelanggan dalam menyampaikan keluhannya melalui berbagai macam media.

6. Kemampuan, kesanggupan, dan pemberdayaan pegawai,

Pegawai diperlukan sebagai profesional yang memiliki kemampuan dan diberdayakan untuk menggunakan pertimbangannya sendiri dalam melakukan hal-hal yang dianggap perlu dalam rangka memuaskan kebutuhan pelanggan. Hal ini berati setiap pegawai memahami produk/jasa yang mereka tawarkan dan kebutuhan pelanggan yang berkaitan dengan produk/jasa tersebut. Ini juga berarti bahwa pegawai diberi sumber daya dan dukungan yang diperlukan dalam memenuhi kebutuhan pelanggan

7. Penyempurnaan produk dan proses secara terus-menerus.

Organisasi yang bersifat customer driven melakukan setiap tindakan yang diperlukan untuk secara terus-menerus memperbaiki produk/jasa dan proses yang menghasilkan produk/jasa tersebut. Pendekatan ini diwujudkan dalam hal, yaitu a) kelompok fungsional internal bekerja sama untuk mencapai sasaran bersama, b) praktik-praktik terbaik yang berkaitan dengan bidang pendidikan dipelajari dan dilaksanakan, c) waktu siklus riset dan pengembangan secara terus-menerus dikurangi, d) setiap masalah diatasi dengan segera, dan e) investasi dalam pengembangan ide-ide inovatif dilakukan.

Ketujuh karakteristik tersebut dapat digunakan sebagai pedoman dan membentuk fokus pada pelanggan. Pada tahap awal setiap organisasi perlu melakukan analisis diri. Dalam analisis ini akan ditentukan karakteristik mana yang sudah dan belum ada dalam organisasi. Organisasi perlu mewujudkan karakteristik yang belum ada tersebut sehingga fokus pada pelanggan dapat terbentuk.

\section{Faktor Internal Koperasi}

Secara teoritis, faktor internal seringkali mengacu sebagai potensi dan kemampuan sumber daya yang dimiliki secara internal oleh organisasi atau perusahaan, baik secara kuantitatif maupun secara kualitatif. Tingkat potensi dan kemampuan sumber daya yang mencerminkan profil organisasi ini akan melahirkan dua kemungkinan yaitu pada kekuatan dan kelemahan. Analisis internal dimaksudkan untuk mengidentifikasi keunggulan bersaing (competitive advantage) organisasi (David, Fred $\mathrm{R}$, 2009). Lingkungan internal merupakan suatu kondisi yang tercipta karena proses yang terjadi dari dalam organisasi. Analisis lingkungan internal ini bersifat dapat dikendalikan oleh organisasi. Hariadi (2005) menambahkan bahwa faktor internal merupakan sejumlah variabel yang meliputi kekuatan 
dan kelemahan yang berada di dalam organisasi, dimana dalam jangka pendek variabel tersebut berada di dalam pengendalian manajer puncak.

Koperasi memiliki karakteristik yang berbeda dibandingkan dengan organisasi bisnis lainnya. Pada koperasi, sebenarnya nilai-nilai yang ditawarkan tidak hanya dalam pengertian ekonomis, tetapi juga menyangkut nilai-nilai ideologis seperti kemandirian, solidaritas, demokrasi, kebebasan, keadilan, altruisme dan pengembangan sosial (Munkner, 1987).

Koperasi memiliki tangible asset dan intangible asset, oleh Ulrich (1998) menyebutkan bahwa aset perusahaan tidak lagi ditentukan oleh seberapa besar nilai investasinya pada asset-aset yang wujud (tangible) semata, tetapi juga lebih kepada asset tak berwujud (intangible asset). Asset intangible koperasi adalah modal koperasi yang tidak berwujud atau bersifat abstrak yang muncul melalui jaringan hubungan interaksi dan kerjasama dengan orang lain. Modal ini disebut sebagai modal sosial, menurut Bullen dan Onyx (2000), komponen modal sosial berupa partisipasi dalam jaringan, hubungan timbal balik, trust, control social, kebersamaan, dan proaktif.

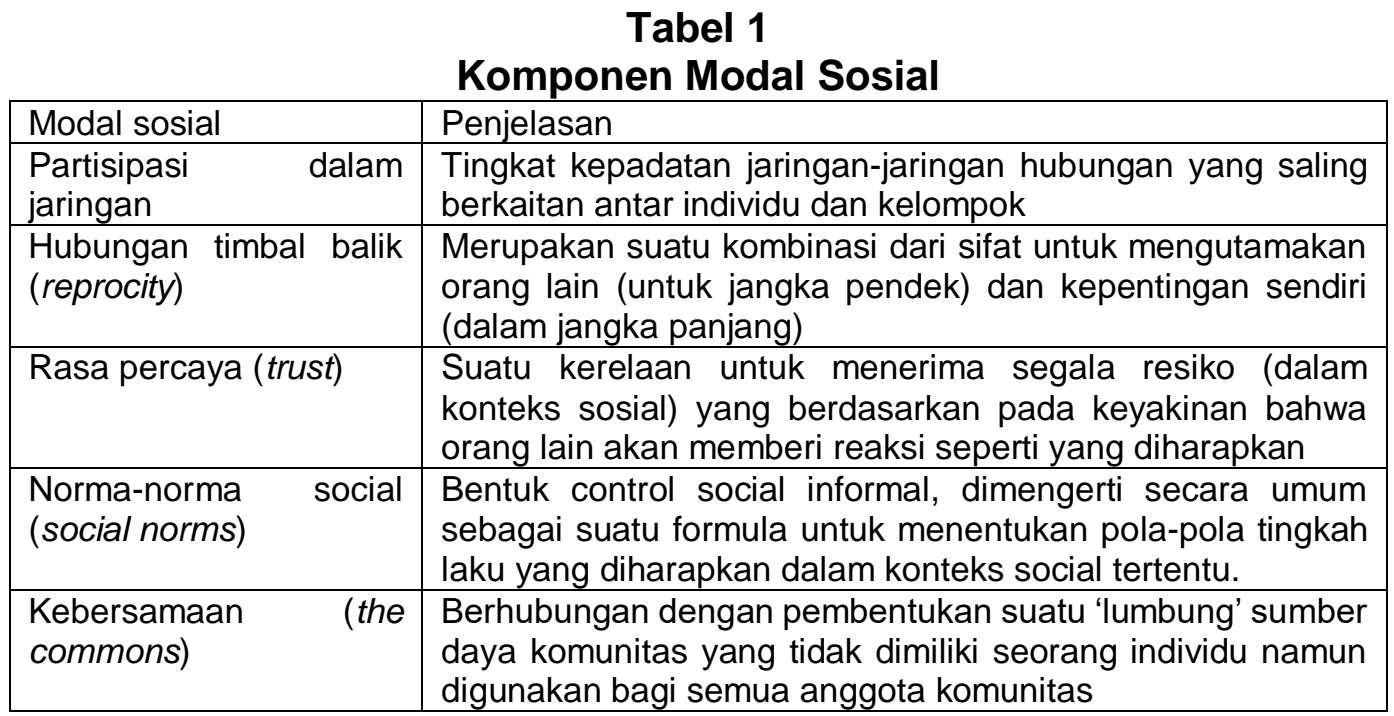

Sumber: Bullen dan Onyx, 2000

Sedangkan faktor internal yang mempengaruhi perkembangan usaha koperasi menurut Soedirman, (2006), meliputi: partisipasi anggota, solidaritas antar anggota koperasi, pengurus koperasi yang juga tokoh masyarakat, skala usaha, perkembangan modal, ketrampilan manajerial, jaringan pasar, jumlah dan kualitas SDM koperasi, pemilikan dan pemanfaatan perangkat teknologi produksi, sistem manajemen, dan kinerja pengurus.

\section{Faktor Eksternal Koperasi}

Sedangkan audit eksternal mengacu pada penekanan identifikasi dan evaluasi trend dan kejadian yang berada di luar kendali perusahaan. 
Mengenai faktor eksternal ini, Hariadi (2005) menjelaskan bahwa lingkungan eksternal merupakan sejumlah variabel yang mengacu pada peluang dan ancaman yang berada di luar organisasi dalam jangka pendek dan biasanya tidak dapat dikendalikan oleh manajemen puncak organisasi. Tujuan dari audit eksternal adalah mengembangkan peluang yang dapat menguntungkan perusahaan, serta menghindari ancaman yang bisa merugikan perusahaan. Menurut David (2016), dalam mengaudit eksternal, sebuah perusahaan harus mengumpulkan informasi mengenai lima kekuatan eksternal utama yang mencakup: 1). Kekuatan ekonomi, 2). kekuatan sosial, budaya, demografis dan lingkungan, 3). kekuatan pemerintah dan hukum, 4). kekuatan teknologi, dan 5). kekuatan kompetitif yang secara signifikan dapat menguntungkan atau membahayakan organisasi di masa yang akan datang.

Soedirman (2006) memaparkan faktor eksternal yang dapat mempengaruhi pertumbuhan dan perkembangan koperasi antara lain :

a. Komitmen pemerintah untuk menempatkan koperasi sebagai soko guru perekonomian nasional.

b. Sistem prasarana, pelayanan, pendidikan dan penyuluhan.

c. Iklim pendukung perkembangan koperasi dari pemerintah.

d. Dicabutnya Fasilitas Tertentu Oleh Pemerintah

e. Tingkat harga

\section{Daya Saing Koperasi}

Sebagai bagian dari strategi, daya saing bukan dimaksudkan untuk "memusnahkan" pesaing, akan tetapi menjadi yang terbaik bagi pelanggannya dibandingkan pesaingnya. Menjadi yang terbaik adalah menyampaikan produk dan pelayanan yang terbaik kepada pelanggan dibanding pesaingnya. Definisi daya saing selalu mengalami perkembangan, dalam pembentukan rantai nilai (value of chain), daya saing dapat ditunjukkan dari kemampuan perusahaan untuk mendatangkan nilai baik dari kegiatan primer maupun pendukung.

Keunggulan bersaing disebabkan oleh pilihan strategi yang dilakukan perusahaan untuk merebut peluang pasar. Ada tiga strategi yang dapat dilakukan perusahaan untuk memperoleh keunggulan bersaing yaitu: cost leadership, diferensasi, fokus. Perusahan dapat memperoleh keunggulan bersaing yang lebih tinggi dibanding dengan pesaingnya jika perusahaan dapat memberikan harga jual yang lebih murah daripada harga yang diberikan para pesaingnya dengan nilai/kualitas yang sama. Harga jual yang lebih rendah dapat dicapai oleh perusahaan tersebut karena memanfaatkan skala ekonomis, efisiensi produksi, penggunaan teknologi, kemudahan akses dengan bahan baku, dan sebagainya. Perusahaan juga dapat melakukan strategi diferensiasi dengan menciptakan persepsi terhadap nilai tertentu pada konsumen misalnya, perespsi terhadap keunggulan kinerja produk, inovasi produk, pelayanan yang lebih naik, dan brand image yang lebih unggul. Selain itu strategi fokus juga dapat diterapkan untuk memperoleh keunggulan bersaing sesuai dengan segmentasi pasar sasaran yang diharapkan. (Porter, 1993). 
Koperasi akan memiliki keunggulan kompetitif ketika pelanggan (terutama anggota) mendapatkan kepuasan melalui kesan bahwa produk atau layanan lebih baik daripada produk atau layanan pesaing. Untuk itu koperasi harus memperhatikan lima poin dalam mengembangkan daya saing, yang fokus pada pelanggan sebagai anggota atau bukan anggota, kesetiaan pada kualitas, perhatian terhadap kenyamanan, konsentrasi terhadap inovasi, dan dedikasi terhadap pelayanan (Hendar, 2010).

Koperasi sebagai badan usaha akan selalu bersaing dengan pelaku usaha lainnya. Indikator koperasi yang bisa memenangkan persaingan adalah koperasi yang mampu menarik anggota sebanyak mungkin. Kemampuan koperasi yang bisa menawarkan kelebihan khusus yang tidak bisa diberikan oleh perusahaan lain akan menarik anggota baru untuk masuk ke dalam koperasi tersebut. Syarat koperasi untuk bisa menarik masyarakat menjadi pemilik koperasi sekaligus sebagai pengguna layananlayanan yang diberikan oleh koperasi menurut Hendar (2010) antara lain adalah:

1. Koperasi harus dapat menghasilkan kelebihan yang sama dengan perusahaan pesaingnya. Koperasi harus menjadi pemenang dalam persaingan atau mempunyai keunggulan bersaing (competitive advantages) dari para pesaingnya.

2. Anggota koperasi harus mampu mempertahankan keunggulan itu dengan cara berpartisispasi aktif pada koperasinya dan mengendalikan manajemen koperasi agar mampu dan bersedia mempromosikan kepentingan para anggota.

Jadi untuk menganalisis keunggulan koperasi harus ada tiga pemain yang diperhitungkan, yaitu: koperasi itu sendiri (cooperative), para anggota atau pelanggan (customer/member) dan pesaing (competitor). Berbagai strategi perusahaan dalam rangka meraih keunggulan berkesinambungan seperti yang diuraikan pada akhirnya akan bermuara pada sejauh mana masing-masing perusahaan memberikan nilai-nilai yang dirasakan pelanggannya. Jika perusahaa mampu menawarkan nilai-nilai yang lebih besar ketimbang nilai-nilai yang ditawarkan perusahaan lain, maka perusahaan itulah yang akan memperoleh keunggulan bersaing.

\section{METODE PENELITIAN}

Penelitian ini tergolong dalam penelitian kuantitatif, dan termasuk field research dengan pendekatan explanatory atau confirmatory, yaitu penelitian yang bertujuan untuk menguji teori dengan cara menyoroti hubungan antar variabel dengan menggunakan kerangka pemikiran terlebih dahulu, kemudian dirumuskan dalam bentuk hipotesis.

Penelitian ini dilaksanakan mulai bulan Januari 2018 sampai Mei 2018, terhadap pengurus, pengawas, manajer, karyawan dan anggota dari 7 koperasi di kota Batu yang telah dipilih secara purposive.

\section{Populasi dan Sampel}

Pengambilan sampel pada penelitian ini memakai metode purposive sampling yang merupakan salah satu teknik sampling non random dimana peneliti menentukan pengambilan sampel dengan cara menetapkan ciri-ciri 
khusus yang sesuai dengan tujuan penelitian sehingga diharapkan dapat menjawab permasalahan penelitian.

Ada tujuh koperasi di wilayah kota Batu yang dijadikan lokasi untuk penyebaran angket. Pemilihan ketujuh koperasi ini sebagai sampel penelitian didasarkan pada beberapa pertimbangan peneliti, antara lain yaitu:1.Umur koperasi antara 5-10 tahun; 2. Jumlah anggota yang relatif besar; 3. Jenis usaha yang dilakukan oleh koperasi; 4.Kemudahan akses untuk dimasuki (untuk penyebaran angket); 5. Keterbatasan waktu dan dana penelitian.

Tabel 2

Koperasi Obyek Penelitian

\begin{tabular}{|l|l|l|}
\hline Nama Koperasi & Alamat Koperasi & $\begin{array}{l}\text { Jml } \\
\text { Resp. }\end{array}$ \\
\hline KUD Batu & Jl. Diponegoro 8, Batu & 2.597 \\
\hline Kop. Agrobis Bumi Makmur & Jl. Raya Dadaprejo 1, Batu & 851 \\
\hline Kop. An-nisa & Jl. Kawi 16, Batu & 380 \\
\hline Kop. Ikhtiyar Butuhe Urip (IBU) & Jl. Sidomulyo 74, Batu & 585 \\
\hline Kop. Kartini Mandiri & Jl. Giripurno 54, Batu & 127 \\
\hline Kop. Bin Auf & Jl. Ry. Arjuno Junggo, Batu & 549 \\
\hline Kop. Brosem & Jl. Bromo I/24, Batu & 235 \\
\hline \multicolumn{2}{|l|}{ Jumlah } & 5.324 \\
\hline
\end{tabular}

Sumber: data primer yang diolah, 2018

Tabel 3

Distribusi Unit Sampel

\begin{tabular}{|l|l|l|}
\hline Nama Koperasi & Resp. & $\begin{array}{l}\text { Sampel } \\
\mathbf{( 3 \% )}\end{array}$ \\
\hline KUD Kota Batu & 2.597 & $77,91 \approx 78$ \\
\hline $\begin{array}{l}\text { Kop. Agrobis Bumi } \\
\text { Makmur }\end{array}$ & 851 & $25,53 \approx 26$ \\
\hline Kop. An-Nisa & 380 & $11,4 \approx 11$ \\
\hline $\begin{array}{l}\text { Kop. Ikhtiyar Butuhe } \\
\text { Urip }\end{array}$ & 585 & $17,55 \approx 18$ \\
\hline Kop. Kartini Mandiri & 127 & $3,81 \approx 4$ \\
\hline Kop. Bin Auf & 549 & $16,47 \approx 16$ \\
\hline Kop. Brosem & 235 & $7,05 \approx 7$ \\
\hline TOTAL & 5.324 & $\mathbf{1 6 0}$ \\
\hline
\end{tabular}

Sumber: Data yang diolah, 2018

Ukuran sampel minimal yang diambil menggunakan rumus tabel Yount (Arikunto, 2006), dimana populasi sebesar lebih dari 5.000 responden maka besarnya sampel yang diambil adalah sebesar $3 \%$, seperti yang tercantum pada tabel 3.

\section{Operasionalisasi Variabel}

Dalam analisis data, supaya dapat dihitung, variabel perlu dijabarkan ke dalam konsep empirik dan konsep analisis dalam bentuk indikatorindikator yang terukur. Konsep dan operasional variabel penelitian diuraikan pada gambar 1 .

\section{Metode Analisis Data}

Data dikumpulkan dalam pernyataan yang disebar melalui angket. Jawaban setiap item instrument diukur dengan menggunaan skala likert. Selanjutnya item pertanyaan tersebut diuji tingkat validitas dan reliabilitasnya terlebih dahulu. 
Metode analisis data yang dipakai adalah analisis jalur (path analysis) yang bertujuan untuk menguji model yang didukung oleh data, dengan cara membandingkan matriks korelasi teoritis dan matriks korelasi empiris (Pedazur, 1982). Jika matriks keduanya relatif sama, maka model dikatakan cocok. Pengujian dilakukan dengan menggunakan koefisien determinasi ganda.

Selanjutnya dilakukan uji regresi variabel moderasi untuk mengetahui variabel yang dapat memperkuat atau memperlemah pengaruh variabel independen terhadap variabel dependen (Riduwan dan Sunarto, 2011). Proses yang ditempuh dalam analisis data adalah dengan menggambar model jalur, menghitung koefisien regresi pada jalur yang dirumuskan secara parsial dan simultan, kemudian melakukan uji regresi variabel moderasi dengan menggunakan uji interaksi Moderated regression Analysis (MRA).

\section{HASIL ANALISIS DATA}

Angket disebar kepada pengurus, pengawas, manajer, karyawan dan anggota dari ketujuh koperasi yang dipilih. Angket yang disebar sebanyak 160 angket pada jumlah sampel yang telah ditentukan. Angket disebar melalui metode offline (langsung bertemu responden) dan online (menyebarkan lewat email dan whatsapp). Dari keseluruhan angket yang disebar, angket yang diisi dan dikembalikan oleh respoden serta dapat diolah adalah sebanyak 133 angket, sedangkan sisanya tidak diisi oleh responden. Dengan demikian dapat diperoleh jumlah prosentase untuk angket yang siap diolah menjadi data adalah sebesar $83 \%$.

Berdasarkan jenis kelaminnya, didapatkan responden wanita yang menjawab angket yaitu sebanyak 79 responden atau sebesar $59,4 \%$. Sedangkan responden yang berjenis kelamin pria adalah sebanyak 54 orang atau sebesar $40,6 \%$. Kemudian dari rentang usia, responden yang terjaring memiliki usia kurang dari 20 tahun adalah 0\%, kemudian usia 2130 tahun sebanyak 25 responden atau sebesar 18,8\%. Responden yang memiliki rentang usia antara 31-40 tahun adalah sebanyak 57 orang, usia ini adalah rentang usia terbesar dari total responden, yaitu sebesar $42,9 \%$. Selanjutnya diperoleh data mengenai responden yang mempunyai usia berkisar antara 41-50 tahun adalah sebanyak 40 orang atau sebesar $30,1 \%$. Dan terakhir adalah responden yang memiliki usia di atas 50 tahun yaitu sebanyak 11 orang atau sebesar $8,3 \%$.

Analisis penggolongan responden berikutnya adalah diklasifikasikan berdasarkan tingkat pendidikannya. Berdasarkan data yang disajikan pada tabel 4.8, diketahui bahwa, responden pada penelitian ini terbesar adalah lulusan Sarjana (S1/S2), yaitu sebanyak 68 responden atau sebesar $51,1 \%$ dari total responden. Hal ini mengindikasikan bahwa koperasi sudah dipegang oleh sumber daya manusia yang memiliki ilmu pengetahuan dan pendidikan tinggi. Responden terbesar selanjutnya adalah responden yang memiliki tingkat pendidikan rendah yaitu SMP/SMA, sebanyak 57 responden atau sebesar $42,9 \%$. Sisanya sebanyak 8 responden atau 
sebesar $6 \%$ memiliki tingkat pendidikan menengah atau setara Diploma $1 / 2 / 3$.

Selanjutnya responden akan dianalisis berdasarkan klasifikasinya berdasarkan posisi responden dalam koperasi yang bersangkutan. Dari data yang diperoleh, posisi terbanyak adalah responden sebagai anggota, dimana ditempati oleh sebanyak 76 orang atau sebesar $57,1 \%$ dari total responden. Posisi terbesar selanjutnya adalah responden yang bekerja di koperasi sebagai karyawan yaitu sebanyak 40 orang atau sebesar 30,1\%. Posisi karyawan ini ada yang merupakan anggota koperasi itu sendiri, tetapi ada juga yang bukan berasal dari anggota (pihak luar koperasi). Jabatan selanjutnya yaitu pengurus yang menjadi responden, yaitu sebanyak 11 orang atau sebesar 8,3\%. Dilanjutkan oleh pengawas sebanyak 4 orang atau sebesar $3 \%$, dan terakhir adalah manajer sebanyak 2 orang atau sebesar $1,5 \%$.

\section{Deskripsi Tanggapan Responden}

Angket yang disebarkan, menghasilkan skor tertinggi pada variabel customer focus yang ditunjukkan pada instrument pernyataan tentang kemitraan, dengan total index sebesar $85,26 \%$. Sedangkan total nilai terendah diperoleh pada instrument pernyataan mengenai identifikasi tingkat kepuasan/ ketidakpuasan anggota dengan total index sebesar $61,35 \%$. Hasil ini mengindikasikan bahwa koperasi telah menjalin kemitraan dengan para anggotanya, tetapi koperasi belum melakukan identifikasi terhadap kepuasan atau ketidakpuasan anggotanya dengan baik.

Selanjutnya dilakukan penghitungan hasil angket untuk mengukur tanggapan responden mengenai faktor internal yang dimiliki koperasi dengan tujuan untuk melihat seberapa besar kekuatan dan kelemahan koperasi dalam mempertahankan keunggulan bersaingnya. Variabel faktor internal terdiri dari 11 item pernyataan, yang meliputi tentang pengukuran aset berwujud dan aset tidak berwujud, antara lain adalah: aset fisik koperasi, aset teknologi yang dimiliki koperasi, aset SDM, aset pemasaran, aset pendidikan dan pengembangan, partisipasi dalam jaringan, birokrasi, trust (kepercayaan), reprocity (interaksi sesama anggota), kesamaan kepentingan, dan profesionalitas tanggung jawab. Secara statistik frekuensi jawaban responden tersebut dapat digambarkan bahwa, dari 133 responden menghasilkan hasil tertinggi dan terendah pada perhitungan total nilai skornya. Total skor tertinggi diperoleh instrument pertanyaan tentang partisipasi anggota dalam jaringan dengan nilai index sebesar $79,70 \%$. Sedangkan skor terendah ada pada instrument pertanyaan mengenai aset teknologi dengan total index sebesar $59,55 \%$. Hal ini menunjukkan bahwa koperasi memiliki sumber daya tidak berwujud berupa motivasi anggota dalam berkoperasi yaitu keinginan untuk berpartisipasi dalam jaringan, namun koperasi belum didukung dengan pemilikan dan penggunaan aset teknologi yang baik. 
Selanjutnya analisis deskriptif mengenai tanggapan responden terhadap faktor eksternal yang dimiliki koperasi dituangkan pada angket yang terdiri dari 8 item pernyataan untuk mengidentifikasikan faktor peluang dan ancaman yang ada di luar kendali koperasi. Beberapa faktor eksternal yang dituangkan ke dalam angket ini antara lain adalah: mengenai pandangan masyarakat umum terhadap koperasi, fasilitas dana dan pendidikan yang diberikan pemerintah, produk dan harga pesaing, kerja sama dengan pihak lain, perubahan teknologi, serta peluang untuk melayani non anggota. Hasil tertinggi ditunjukkan pada instrument pertanyaan dengan total index sebesar $79,25 \%$, tentang pandangan masyarakat pada koperasi, dan hasil terendah ditunjukkan oleh item pertanyaan tentang produk pesaing, dengan total index sebesar $60,90 \%$. Dari hasil tersebut mengindikasikan bahwa masih banyaknya stigma negatif dari masyarakat terhadap koperasi, dan produk pesaing yang dianggap tidak mengancam daya saing koperasi.

Analisis deskriptif yang terakhir dilakukan pada item pernyataan variabel daya saing koperasi. Jumlah pernyataan yang disajikan untuk mengukur variabel daya saing ini sebanyak 10 item pernyataan. Tanggapan yang diukur dari responden bertujuan untuk mengetahui kemauan dan kemampuan koperasi dalam rangka melayani anggota, meningkatkan pelayanan, memperbarui produk, melayani pasar non anggota, meningkatkan partisipasi anggota, mempertahankan loyalitas anggota, meningkatkan kepercayaan anggota, dan kemauan anggota merekomendasikan koperasi kepada non anggota. Diketahui bahwa skor tertinggi diperoleh instrument pertanyaan dengan jumlah skor index sebesar $78,80 \%$, tentang pemuasan anggota terlebih dahulu. Sedangkan jumlah skor terendah diperoleh dengan total index sebesar 60,90\%, mengenai pembatasan layanan non anggota. Hal ini berarti bahwa sebelum koperasi melakukan ekspansi pasar terhadap non anggota, anggota menghendaki koperasi untuk melayani anggota dengan sebaik-baiknya sehingga pemuasan anggota lebih dulu bisa tercapai.

\section{Uji Hipotesis}

Uji t dilakukan untuk menguji hipotesis pertama, kedua dan ketiga, yaitu untuk menguji ada atau tidaknya pengaruh parsial (sendiri) yang diberikan variabel independen $(X)$ terhadap variabel dependen $(Y)$.

\section{Tabel 4}

Ringkasan Hasil Pengujian Hipotesis dengan Uji t

\begin{tabular}{|l|l|l|l|l|}
\hline Hip & Pernyataan & $\begin{array}{l}\text { Nilai } \\
\text { t hit }\end{array}$ & Keterangan & $\begin{array}{l}\text { Besarnya } \\
\text { Pengaruh }\end{array}$ \\
\hline H1 & $\begin{array}{l}\text { Strategi customer focus berpengaruh } \\
\text { signifikan terhadap daya saing koperasi }\end{array}$ & 5,258 & $\begin{array}{l}\mathbf{H}_{\mathbf{1}} \text { diterima } \\
\mathrm{H}_{0} \text { ditolak }\end{array}$ & $31,7 \%$ \\
\hline $\mathrm{H} 2$ & $\begin{array}{l}\text { Faktor internal berpengaruh signifikan } \\
\text { terhadap daya saing koperasi }\end{array}$ & 8,499 & $\begin{array}{l}\mathbf{H}_{\mathbf{1}} \text { diterima } \\
\mathrm{H}_{0} \text { ditolak }\end{array}$ & $58,8 \%$ \\
\hline H3 & $\begin{array}{l}\text { Faktor eksternal berpengaruh signifikan } \\
\text { terhadap daya saing koperasi }\end{array}$ & $\mathbf{1 , 3 4 7}$ & $\begin{array}{l}\mathbf{H}_{\mathbf{1}} \text { ditolak } \\
\mathrm{H}_{0} \text { diterima }\end{array}$ & $7,2 \%$ \\
\hline
\end{tabular}

Sumber: data primer yang diolah, 2018 
Uji selanjutnya yang dilakukan adalah uji $\mathrm{F}$, yang bertujuan untuk mengetahui ada atau tidaknya pengaruh simultan (bersama-sama) yang diberikan variabel independen $(X)$ terhadap variabel dependen $(Y)$.

Tabel 5

Hasil Uji F

\begin{tabular}{|c|c|c|c|c|c|c|}
\hline \multicolumn{2}{|c|}{ Model } & \multirow{2}{*}{\begin{tabular}{|l} 
Sum \\
Squares
\end{tabular}} & Df & Mean Square & $\mathrm{F}$ & Sig. \\
\hline 1 & Regression & & 3 & 8.197 & 264.139 & $.000^{\mathrm{a}}$ \\
\hline & Residual & 4.003 & 129 & .031 & & \\
\hline & Total & 28.593 & 132 & & & \\
\hline
\end{tabular}

a. Predictors: (Constant), Faktor Eksternal, Customer Focus, Faktor Internal

b. Dependent Variable: Daya Saing

Sumber: hasil perhitungan SPSS, 2018

Dari tabel 5 di atas, diketahui output nilai Sig. pengaruh $X_{1}, X_{2}, X_{3}$ secara simultan terhadap $Y$ adalah sebesar $0,000<0,05$ dan nilai $F$ hitung $264,139>\mathrm{F}$ tabel 2,67 sehingga dapat disimpulkan bahwa terdapat pengaruh customer focus $\left(\mathrm{X}_{1}\right)$, faktor internal $\left(\mathrm{X}_{2}\right)$ dan faktor eksternal $\left(\mathrm{X}_{3}\right)$ secara simultan terhadap daya saing $(Y)$, dan hasil ini menunjukkan hubungan goodness of fit yang tinggi.

Hasil perhitungan koefisien determinasi menghasilkan besarnya nilai $R$ square adalah 0,860 , dan ini berarti bahwa pengaruh ketiga variabel dependen customer focus $\left(X_{1}\right)$, faktor internal $\left(X_{2}\right)$, dan faktor eksternal $\left(X_{3}\right)$ secara simultan terhadap variabel daya saing $(Y)$ adalah sebesar $86,0 \%$, sedangkan sisanya 14,0\% dijelaskan oleh sebab lain di luar model ini.

Selanjutnya untuk menguji hipotesis keempat dan kelima, maka dilakukan uji moderasi (MRA). Dalam uji moderasi ini, ada dua persamaan yang dipakai untuk menguji kuat/lemahnya hubungan ini adalah:

1. $Y=a+b 1 \times 1$

2. $Y=a+b 1 \times 1+b 2 \times 2+b 3 \times 1 \times 2$

Dari dua persamaan tersebut nantinya akan dibandingkan hasil yang didapat sebelum ada variabel moderator dan setelah adanya peranan variabel moderator.

Persamaan pertama diperoleh hasil:

$$
Y=1,183+0,699 \times 1
$$

Hasil persamaan tersebut dapat diinterpretasikan bahwa nilai konstanta (a) sebesar 1,183 menunjukkan bahwa ketika variabel independen (customer focus) konstan, maka rata-rata daya saing koperasi adalah sebesar 1,183. Sedangkan koefisien regresi (b1) customer focus sebesar 0,699, menunjukkan bahwa setiap kenaikan 1 konstanta pada variabel customer focus akan meningkatkan daya saing koperasi sebesar 0,699 . Koefisien ini bernilai positif menunjukkan bahwa semakin baik customer focus yang dilakukan maka akan semakin baik daya saing yang dimiliki oleh koperasi.

\section{Hasil Uji Moderasi Variabel Faktor Internal}

Diperoleh persamaan regresi:

$Y=-4,890+1,843 X_{1}+2,363 X_{2}-0,489 X_{1} X_{2}$ 
Yang artinya adalah nilai konstanta (a) sebesar $-4,890$ dengan nilai negatif pada persamaan tersebut menunjukkan bahwa jika variabel faktor internal dihilangkan, maka ada kecenderungan nilai daya saing koperasi mengalami penurunan sebesar $-4,890$. Sedangkan koefisien regresi (b1) sebesar 1,843 menunjukkan bahwa setiap kenaikan 1 konstanta pada variabel customer focus akan meningkatkan daya saing koperasi sebesar 1,843. Koefisien ini bernilai positif menunjukkan bahwa semakin baik customer focus yang dilakukan maka akan semakin baik daya saing yang dimiliki oleh koperasi. Koefisien regresi (b2) sebesar 2,363 artinya bahwa setiap kenaikan 1 konstanta variabel faktor internal akan meningkatkan daya saing koperasi sebesar 2,363. Koefisien regresi (b3) bernilai negatif, yaitu -0,489 menunjukkan bahwa setiap penurunan 1 konstanta variabel faktor internal, maka akan menurunkan daya saing koperasi sebesar 0,489 .

\section{Hasil Uji Moderasi Variabel Faktor Eksternal}

Diperoleh persamaan regresi:

$Y=-1,384+1,206 X_{1}+0,988 X_{2}-0,211 X_{1} X_{2}$

Yang artinya adalah nilai konstanta (a) sebesar $-1,384$ dengan nilai negatif pada persamaan tersebut menunjukkan bahwa jika variabel faktor eksternal dihilangkan, maka ada kecenderungan nilai daya saing koperasi mengalami penurunan sebesar -1,384. Sedangkan koefisien regresi (b1) sebesar 1,206 menunjukkan bahwa setiap kenaikan 1 konstanta pada variabel customer focus akan meningkatkan daya saing koperasi sebesar 1,206. Koefisien regresi (b2) sebesar 0,988 artinya bahwa setiap kenaikan 1 konstanta variabel faktor eksternal akan meningkatkan daya saing koperasi sebesar 0,988. Koefisien regresi (b3) bernilai negatif, yaitu -0,211 menunjukkan bahwa setiap penurunan 1 konstanta variabel faktor eksternal, maka akan menurunkan daya saing koperasi sebesar 0,211.

\section{PEMBAHASAN}

\section{Interpretasi Pengaruh Customer Focus terhadap Daya Saing}

Berdasarkan hasil pengujian pada bab sebelumnya, diperoleh output $\mathrm{H} 1$ diterima, bahwa terdapat pengaruh positif pelaksanaan customer focus terhadap peningkatan daya saing koperasi. Hasil pengujian menunjukkan pelaksanaan customer focus secara parsial (sendiri) memberikan kontribusi terhadap peningkatan daya saing koperasi sebesar 31,7\%. Dari hasil tersebut dapat disimpulkan bahwa melaksanakan strategi fokus kepada pelanggan mampu memberi tambahan peningkatan daya saing terhadap organisasi.

\section{Interpretasi Pengaruh Faktor Internal terhadap Daya Saing}

Pengujian hipotesis kedua $(\mathrm{H} 2)$ menyimpulkan bahwa $\mathrm{H} 2$ diterima yaitu terdapat pengaruh yang signifikan antara variabel faktor internal terhadap daya saing koperasi. Hasil perhitungan yang didapatkan menunjukkan besar pengaruh yang diberikan faktor internal secara parsial pada peningkatan daya saing koperasi adalah sebesar 58,8\%. Hasil tersebut menguatkan hasil penelitian terdahulu, bahwa analisis lingkungan internal berpengaruh positif terhadap strategi bersaing, dan strategi bersaing memiliki hubungan positif dengan kinerja perusahaan. (Beal, 
Reginald M, 2000). Analisis lingkungan internal dapat dipakai sebagai strategi pertumbuhan pada perusahaan kecil dan menengah dan menjadi faktor kunci untuk mempertahankan keunggulan kompetitif (Karami, 2008).

\section{Interpretasi Pengaruh Faktor Eksternal terhadap Daya Saing}

Pengujian hipotesis ketiga (H3) menghasilkan kesimpulan bahwa variabel faktor eksternal tidak berpengaruh secara langsung terhadap daya saing koperasi, sehingga $\mathrm{H} 3$ yang ditawarkan dinyatakan ditolak. Perhitungan statistik menghasilkan bahwa variabel faktor eksternal dalam penelitian ini hanya menyumbang pengaruhnya sebesar $7,2 \%$ terhadap peningkatan daya saing koperasi dan tergolong pada pengaruh yang tidak signifikan. Hal ini sesuai dengan hasil yang diperoleh pada penelitian Khikmah \& Wibisono, (2012) yang menyatakan bahwa baik faktor internal maupun eksternal tidak berpengaruh terhadap perkembangan usaha koperasi. Namun berbanding terbalik dengan hasil penelitian yang dilakukan oleh Kraja \& Osmani (2015), yang menemukan bahwa lingkungan eksternal memiliki dampak yang lebih besar daripada lingkungan internal terhadap keberhasilan UMKM.

\section{Interpretasi Pengaruh Customer Focus terhadap Daya Saing dimoderasi Faktor Internal}

Dari hasil output perhitungan diperoleh temuan bahwa ketiga variabel secara simultan (bersama-sama) memberikan kontribusi pada peningkatan daya saing sebesar $86,0 \%$, sedangkan sisanya sebesar $14,0 \%$ dipengaruhi oleh sebab lain di luar model ini. Sedangkan hasil koefisien determinasi pengaruh variabel customer focus terhadap daya saing sebelum adanya variabel moderasi adalah sebesar $73,5 \%$, dan setelah dimoderasi oleh variabel faktor internal, besarnya pengaruh customer focus terhadap daya saing koperasi mengalami kenaikan sebesar $20,1 \%$ menjadi 93,6\%. Dengan demikian dapat ditarik kesimpulan bahwa terdapat kecenderungan peningkatan pengaruh akibat adanya interaksi faktor internal pada pelaksanaan strategi customer focus.

\section{Interpretasi Pengaruh Customer Focus terhadap Daya Saing dimoderasi Faktor Eksternal}

Pengujian yang dilakukan pada bab sebelumnya diperoleh output bahwa adanya interaksi yang diberikan oleh faktor eksternal, dapat menaikkan besarnya kontribusi yang diberikan customer focus terhadap daya saing koperasi. Sebelum dimoderasi oleh faktor eksternal, besarnya koefisien pengaruhnya sebesar $73,5 \%$ dan setelah dimoderasi meningkat sebesar $6,7 \%$ menjadi $80,2 \%$. Karena pemberian variabel faktor eksternal dapat meningkatkan pengaruh customer focus terhadap peningkatan daya saing dan hasilnya signifikan, maka dapat disimpulkan bahwa variabel faktor eksternal merupakan variabel moderating, sehingga H5 diterima.

\section{SIMPULAN DAN SARAN}

Strategi customer focus berpengaruh secara signifikan terhadap peningkatan daya saing koperasi secara parsial maupun simultan. Hal ini berarti koperasi mampu memberi tambahan peningkatan daya saing terhadap organisasi dengan melakukan strategi customer focus kepada anggotanya,. Inti praktek customer focus adalah dengan memenuhi 
kebutuhan para anggota dan berkembang bersama-sama anggota. Strategi customer focus yang bisa dijalankan oleh koperasi antara lain adalah dengan cara menjalin kemitraan dengan para anggotanya, melaksanakan kontak langsung dengan para anggota dan melibatkan anggota dalam penyusunan program kerja koperasi.

Faktor internal berpengaruh secara signifikan baik secara parsial maupun simultan terhadap peningkatan daya saing koperasi. Faktor internal yang dimiliki koperasi ini terdiri dari sumber daya berwujud (tangible asset) dan sumber daya tidak berwujud (intangible asset) yang berperan dalam mempertahankan loyalitas anggota dalam berkoperasi. Anggota koperasi mempertahankan keanggotaannya untuk menjadi bagian dari koperasi dikarenakan oleh adanya faktor yaitu: adanya kesempatan bagi anggota untuk berpartisipasi aktif dalam koperasi, koperasi menyediakan akses pemasaran yang digunakan untuk pengembangan usaha anggotanya, dan koperasi didukung oleh pengurus, manajer, dan karyawan yang handal dalam melaksanakan tugasnya.

Dalam penelitian ini, faktor eksternal tidak berpengaruh secara signifikan terhadap peningkatan daya saing koperasi. Hal ini mengindikasikan bahwa stigma negatif terhadap koperasi dari masyarakat masih sangat berpengaruh, sehingga koperasi tidak banyak diminati oleh masyarakat sekitar. Selain itu koperasi juga belum memiliki kesadaran untuk memindai lingkungan eksternalnya dengan baik. Manajerial koperasi belum mampu merespon keadaan dan situasi di luar koperasinya untuk mengenali ancaman dan peluang yang ada. Sehingga dapat disimpulkan, faktor eksternal terbesar yang menghambat daya saing koperasi adalah stigma negatif dari masyarakat mengenai koperasi, faktor produk pesaing, harga pesaing, dan peluang untuk memberikan pelayanan pada non anggota. Dibutuhkan skill manajerial untuk merubah faktor-faktor eksternal yang tidak mendukung perkembangan daya saing tersebut menjadi sebuah peluang yang dapat dipakai untuk meraih keuntungan.

Temuan selanjutnya dalam penelitian ini adalah memutuskan bahwa variabel faktor internal adalah variabel moderating yang berperan menambah kontribusi pada peningkatan daya saing koperasi. Dari hasil perhitungan dan pembahasan dapat ditarik kesimpulan bahwa terdapat kecenderungan peningkatan pengaruh pada daya saing koperasi akibat adanya interaksi faktor internal pada pelaksanaan strategi customer focus. Bahwa pelaksanaan customer focus semakin baik apabila koperasi mampu mengidentifikasi dan mengelola aset tangible dan aset intangible yang dimilikinya dengan baik pula.

Selanjutnya dapat disimpulkan pula bahwa variabel faktor eksternal juga merupakan variabel moderating. Dengan adanya interaksi dari faktor eksternal, pengaruh customer focus terhadap daya saing koperasi semakin meningkat. Meskipun faktor eksternal berada di luar kendali perusahaan, tetapi faktor eksternal sedikit banyak mempengaruhi perusahaan dalam mengidentifikasi kondisi di sekitar perusahaan yang bisa dijadikan sebagai peluang dalam penentuan strateginya. Pelaksanaan customer focus semakin baik apabila manajerial koperasi mampu menganalisis dan 
mengelola faktor eksternalnya dengan baik pula, sehingga dapat merubah suatu ancaman menjadi peluang yang menguntungkan koperasi.

Penelitian ini hanya mengambil koperasi yang jenis usahanya adalah koperasi produksi, konsumsi dan serba usaha. Sehingga hasil yang didapatkan masih sangat umum dan tidak dapat dipakai untuk koperasi yang bergerak pada usaha jasa simpan pinjam. Sehingga disarankan untuk penelitian yang akan datang untuk mempertimbangkan penggolongan koperasi berdasarkan jenis usahanya.

\section{DAFTAR PUSTAKA}

Agbim. Kenneth Chukwujioke, Godday Orziemgbe Oriarewo, Tor Aondoaver Zever, 2014, Impact of Business Environmental Scanning Behaviour on the entrepreneurial Performance of Micropreneurs: A Conceptual Framework, European Journal of Business and Management www.iiste.org ISSN 2222-1905 (Paper) ISSN 2222-2839 (Online), Vol.6, No.24, 2014

Agustin, Marina Fransisca, 2013, Analisis Kepuasan Anggota terhadap pelayanan KSU Tandangsari, Students e-journal, Vol,2, No.4

Amirullah, 2015, Metode Penelitian Manajemen, Penerbit. Bayumedia Publishing Malang

Arikunto, S., 2006, Prosedur Penelitian Suatu Pendekatan Praktek, Rineka Cipta, Jakarta

Barney. Jay B, 1991, Firm Resources and Sustained Competitive Advantage, Journal of Management, 17(1): 99-120

Beal, Reginald M., 2000, Competing Effectively: Environmental Scanning, Competitive Strategy, And Organizational Performance in Small Manufacturing Firm, Journal Of Small Business Management

Bisungo. Maurice, Kimani Chege, Douglas Musiega, 2014, Effects of Competitive Strategies Adopted By Farmers' Cooperatives on Performance in Butere Sub-County, Kenya, International Journal of Business and Management Invention, ISSN (Online): 2319 - 8028, ISSN (Print): 2319 - 801X, www.ijbmi.org Volume 3 Issue 5\| May. 2014 || PP.11-21

Bullen, P and Jenny Onyx, 2000, Measuring social capital in five communities, Journal of Applied Behavioral Science, vol. 36 no. 1, pp. 23-42. http://dx.doi.org/10.1177/0021886300361002

David, Fred R, 2009, Strategic Management (Manajemen Strategis Konsep), Jakarta, Salemba Empat

David. Fred R, 2016, Manajemen Strategik: Suatu Pendekatan Keunggulan Bersaing, edisi 15, Salemba Empat.

Eliyawati, W., Sutjipta, N., Putra IG Setiawan Adi, 2016, Kualitas Pelayanan dan Tingkat Kepuasan Anggota Koperasi Unit Desa Suraberata Kecamatan Selemadeg Barat, Jurnal Manajemen Agribisnis, Vol. 4, No. 1, Mei, ISSN: 2355-0759

Gemima. Dwi, Samsuri, Indra Cahya Kusuma, 2013, Keunggulan Bersaing Koperasi Berkaitan Dengan Penerapan Intellectual Capital, Manajemen Keanggotaan Dan Partisipasi Anggota, Jurnal 
Manajemen dan Kewirausahaan, Vol. 15, No. 2, September 2013, 191-204 Doi: 10.9744/Jmk.15.2.191-204, ISSN 1411-1438

Goetsch, D. L., dan Davis, S., 1994, Introduction to Total Quality: Quality, Productivity, Competitiveness, Englewood Cliffs: Prentice Hall International, Inc

Gunawan. Dedi Septiadi, Taher Alhabsji, Kusdi Rahardjo, Analisis Lingkungan Eksternal Dan Internal Dalam Menyusun Strategi Perusahaan, (Studi Perencanaan Strategi Komoditi Kelapa Sawit Pada PT. Perkebunan Nusantara III (Persero)), Fakultas IImu Administrasi Universitas Brawijaya Malang

Hanel, Alfred. 1989. Organisasi Koperasi, Pokok-pokok Pikiran Mengenai. Organisasi Koperasi di Negara-negara Berkembang. Yogyakarta: Mida Pustaka.

Hariadi, B., 2005, Strategi Manajemen: Strategi memenangkan Perang Bisnis, Bayumedia Publishing, Jawa Timur.

Hasmi. Muhammad Abu Hassan Asaari, Noorliza Karia, Sahrudeen Kassim, Sofri Yahya, 2004, Business Performance of Small Medium Enterprise: Strategic Planning and Customer Focus, Information Technology and Organizations in the 21 st Century 114

Hendar, 2010, Manajemen Perusahaan Koperasi, Pokok-Pokok Pikiran Mengenai Manajemen Dan Kewirausahaan Koperasi, Erlangga

Karami. Azhdar, 2008, An Investigation On Environmental Scanning And Growth Strategy In High Tech Small And Medium Sized Enterprises), High Technology Small Firms Conference, 21 - 23 May 2008, University of Twente, The Netherlands

Khikmah. Siti Noor, Arif Fajar Wibisono, 2012, Pengaruh Faktor Internal Dan Eksternal Terhadap Perkembangan Usaha Koperasi Di Kota Magelang, Penelitian Dosen pemula, Universitas Muhammadiyah Magelang

Kraja. Ylvije Borici, Elez Osmani, 2015, Importance Of External And Internal Environment In Creation Of Competitive Advantage To Smes. (Case Of Smes, In The Northern Region Of Albania), European Scientific Journal (ESJ), ISSN: 1857-7431, Vol.11, No.13

Kotler, Philip., Keller, Kevin L, 2013, Manajemen Pemasaran, Jilid Kedua, Jakarta: Erlangga

Lindstad, Olav, 1990, Cooperatives as Tools for Development, makalah dalam makalah dalam Seminar Bank Dunia mengenai "Donor Support for the Promotion of Rural Cooperatives in Developing Countries: Special Emphasis SubSaharan Africa", Januari 16-17, Washington, D.C.: the World Bank.

Limakrisna, Nandan dan Wilhelmus Hary Susilo, 2012, Manajemen Pemasaran: Teori dan Aplikasi dalam Bisnis, Jakarta: Mitra Wacana Media

Munkner. Hans H, 1987, Hukum Koperasi, Bandung: Alumni

Parwati. Cyrilla Indri, Inneuke Rose Wijayanti, 2013, Penentuan Faktor Internal Dan Eksternal Dalam Rangka Strategi Pemasaran Guna 
Meningkatkan Daya Saing, Institut Sains \& Teknologi AKPRINDO Yogyakarta

Pedhazur, 1982, Multiple Regression in Behavioral Research: Explanation and Prediction by Elazar J. on Amazon.com

Poerwandari, K, 1998, Pendekatan Kualitatif dalam Penelitian Sosial. Jakarta: LPSP3-UI

Porter E. Michael, 1993, Keunggulan Bersaing , Jakarta, Erlangga

Purba. Tiurniari., Heryenzus, 2018, Analisis Gagalnya Koperasi Di Kota Batam,. Jurnal Akuntansi Barelang, [S.I.], vol. 2, n. 1, p. (174-195), Januari ISSN 2580-5118.

Riduwan \& Sunarto, 2011. Pengantar Statistika untuk Penelitian Pendidikan, Sosial, Ekonomi, Komunikasi, dan Bisnis, Bandung: Cetakan ke 4, Alfabeta.

Rusidi, 1986, Teknik Penelitian Sosial, Universitas. Padjadjaran Bandung

Ropke, Jochen, 2000, Ekonomi Koperasi Teori dan Manajemen, terjemahan oleh Sri Djatnika, Salemba Empat, Jakarta

Soedirman. 2006, Evaluasi Kinerja Koperasi. Jakarta: Rineka Cipta.

Striteska. Michaela, Lucie Jelinkova, 2105, Strategic Performance Management with Focus on the Customer, Procedia - Social and Behavioral Sciences 210 (2015) 66 - 76

Sugiyono, 2009, Metode Penelitian Kuantitatif, Kualitatif dan R\&D, Bandung: Alfabeta

Suharsimi. Arikunto, 1993, Prosedur Penelitian Suatu Pendekatan Praktik, Jakarta: Rineka Cipta

Suliyanto, 2009, Analisis Regresi dengan variabel moderating, slideshare

Suprayitno. Bambang, 2007, Kritik Terhadap Koperasi (Serta Solusinya) Sebagai Media Pendorong Pertumbuhan Usaha Mikro, Kecil, Dan Menengah, Jurnal Ekonomi \& Pendidikan, Volume 4, Nomor 2, November 2007

Suryana, 2010, Metodologi Penelitian: Model Praktis Penelitian Kuantitatif dan Kualitatif, Buku Ajar Perkuliahan, Universitas Pendidikan Indonesia

Tambunan, 2010, KADIN Indonesia, Ukuran Daya Saing Koperasi Dan UKM, Pusat Studi Industri dan UKM, Universitas Trisakti, Kadin Indonesia

Wang, Yonggui dan Hing Po Lo, 2004, An Integrated Framework for Customer value and customer relationship management performance: a customer based perspective from China, managing Service Quality: An International Journal, emeraldinsight

http://depkop.go.id

http://diskopukm.jatimprov.go.id/, 2017, Data Jumlah Koperasi Se-Jawa Timur

https://mamanfathurochman.wordpress.com/artikel/manajemen-stratejik-2, Perencanaan Strategis pada Perusahaan Entrepreneurial Dalam Menghadapi Ketidakpastian Lingkungan Bisnis Eksternal, Research Paper

https://rullyindrawan.wordpress.com/2012/07/30/624, Blue Ocean Strategy dalam Koperasi 